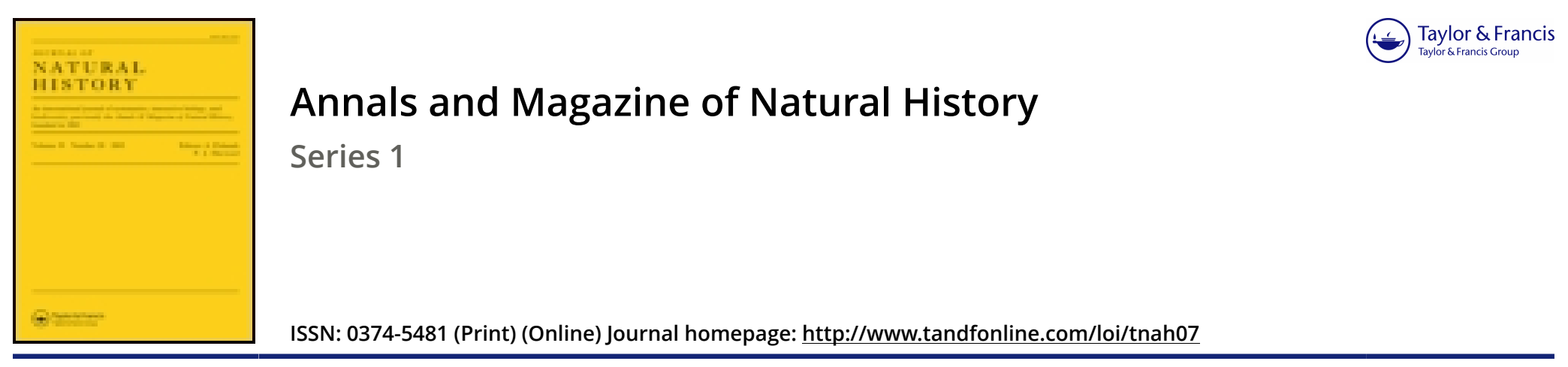

\title{
XXIV.-On the Natural Arrangement of Fishes
}

\author{
W. S. Macleay Esq., A.M., F.L.S.
}

To cite this article: W. S. Macleay Esq., A.M., F.L.S. (1842) XXIV.-On the Natural

Arrangement of Fishes, Annals and Magazine of Natural History, 9:57, 197-207, DOI:

10.1080/03745484209445326

To link to this article: http://dx.doi.org/10.1080/03745484209445326

曲 Published online: 04 Dec 2009.

Submit your article to this journal

Шll Article views: 1

Q View related articles $₫$

4 Citing articles: 1 View citing articles 
the Asterie as formed of the union of numerous individuals attached around a common mouth. In a notice on some points of the organization of the Euryales (Mém. de la Soc. des Sc. Nat. de Neuchâtel, tom. ii.), I have given circumstantial details of the structure and disposition of the solid parts of these animals, and have described comparatively two new specics.

Messrs. Sars and Forbes have reviewed what Otto Fr. Müller has said respecting the Pedicellaria of the Echinodermata, and have added some new observations upon these singular bodies (Hist. of Brit. Starf., p. 155).

[To be continued.]

XXIV.-On the Natural Arranyement of Fishes. By W. S. MAcLear, Esq., A.M., F.L.S., in a Letter to J. M'Clelland, Esq., dated Llizabeth Bay, near Sidncy, N. S. IV., September 12th, 1840*.

Mr Dear Sir,

I cansor find terms to express my gratitude for your kind letter of the 12th March last, and for the very valuable present which it accompanied. I assure you, that your excellent work on Cyprinidace has afforded me the greatest delight, and the more so, inasmuch as I am convinced natural arrangement is always best tested by accurate analysis, and also inasmuch as I am not by any means satisfied with Swainson's arrangement of Fishes. As from everything Swainson writes there is information to be derived, so I assure you, his little rolume on Reptiles and Fishes has not been lost on me; yet the perusal of your Monograph on Indian Cyprinidat has made me recur to my old views on a subject which our common friend Dr. Cantor may hare told you has long occupied my thought; and although perhaps you will deem these views not sufficiently worked out, and rather crude, I cannot refrain from making you acquainted with them, in order' that I may have the benefit of comparing your general arrangement of Fishes with my own.

Fishes form a class of Vertebrata which has never yet been satisfactorily divided into orders. I do not think that Acanthopterygii and Malacopterygii, for instance, are natural orders. In order therefore to arrive at the first great and natural division of Fishes, I think we must commence by incontestable data, or at least by facts that are generally agreed on. Such facts, for instance, I hold to be the three following, viz. 1. The ncar approach of fishes to Batrachian Amphibia, which with Swainson I consider to be made by means of Lophius and Malthe. 2ndly. 'The near approach of fishes to Cetaceous Mammalia, which with him also I consider to take place by means of Selache and the viviparous Sharks. 3rdly. As the grand character of fishes as a class is, their being the most imperfect of Vertebrata,

- From the Calcutta Journal of Nat. Hist. for July 1811.

† Sec Ann. and Mag. Nat. Hist., vol. viii. p. 35. 
the most typical of fishes ought therefore to be the most imperfect of them, i.e. the furthest removed from the type of Vertebrata. Such fishes are evidently the Cyclostomi of Cuvier, such as Myxine, and other genera leading off to Annulosa. Though essentially aberrant, as they relate to vertebrated animals, the Cyclostomous fishes are typical as respects the circle of fishes. Now it is this circle of fishes in which we have the above three data, namely, the two aberrant orders and one typical order : conscquently I arrange the class as folloms, into orders :-

ABERRANT GROUP.

CTENOBRANCIIII. Gills pectinated.

1. PLAGIOSTOMI, Cut. Cartilaginous fish with fixt branchix, leading to Mammalia.

2. STURIONIS, Cuv. Cartilaginous fish with free branchias.

3. OSTINOPTERY GII, MacL. Bony fish with free branchia, leading to Amphibia.

Norsal Grour.

ACTENOBRANCIIII. Fish breathing by gills not pectinated.

4. LOPHOBIRANCHII, Cuv. Bony fish breathing by tufts arranged

5. CYCI.OSTONI, Cur. in pairs along the branchial arches.

Cartilaginous fish breathing by a scrics of cells.

Now this arrangement dificrs from that of Swainson, in making the vast majority of fishes an aberrant group ; but it is the structure, not the number of species it contains, that determines the place of a group in nature. 'The group Ungulata is just as important now, when containing comparatively few genera, as it was in the antediluvian ages, when it contained an immense number of them. Besides, I will venture to say; that the above circular arrangement of fishes expresses their place among Vertebrata better than that of Swainson. I shall differ from him still further as I go on. But in the mean time I must obscrre, that the above and following new names are merely used in order that you may the better understand my meaning. I have been obliged to inrent a technical name for bony fishes with pectinated gills, viz.

\section{OSTINOPTLRYGII,}

which may thus be divided into tribes:-

AEERTANT GROUR.

ACANTHUPTEIRYGII, Artedi. Spincs in first dorsal linrd.-Quere. Are all these Ctemodians of Agrssiz?

1. BALISTINA. Mlectognathi, Cuv. Maxillary bones soldered to the intermaxillaries, and both to the palatine arch. Opercula and gills concenled under the shin.

2. PERCINA.

Bones of the jarrs free and complete. Operculum distinct. Operculum or preoperculum generally with dentated edges, or with spines.

3. FISTULARINA.

Bones of the jar's free and complete. Operculun distinct. Operculum and preoperculum generally with sinooth edges. 
NORBIAL GROUI.

MALACOPTER Y GII, Artedi. Spines in dorsals soft-Quere. Are all these Cycloidians of $\Lambda$ gassiz?

4. PLEURONECTINA. Ventral fins, when existing, inserted under the pectorals, and directly suspended to the bones of the shoulder.

5. CLUPEINA. Abdominales, $C u v$. Ventrals suspended behind the pectorals, and not attached to the boncs of the shoulders.

Obs.-The Balistina, by the confluence of the bones of their jaw, and by the tardy induration of their skeleton, evidently lead off to the Sturgeons, with which they agree in having their free branchix opening by a perforation in the skin behind the temple. 'The Fistularina evidently lead off to the Lopholranchii by Fistularia. Unfortunately $I$ hare not been able to find a near character to separate Fistularina from Percina; but they are natural groups, because each forms a circle. 'The following groups appear to be nearly those into which the above tribes may be naturally divided :-
1. BuListiva.
2. Percise.
3. Fistulatixis.
1. Balistida? ?
1. Chætodontida.
1. Scombridx.
2. Ostraciontidx?
2. Percida.
2. Fistularidx.
3. Cephalaspis? $A g$.
3. Scorpxnids.
4. Orthogoriscida?
4. Cirrhitidx.
5. Sparidx.
3. Gobioidx.
4. Lophitidx.
5. Diodontidx?
5. Labridx.
4. Peeuronectiva.
1. Anguillidx.
2. Tcheneida.
3. Cyclopteridx.
4. Pleuronectides.
5. Gadidx.
5. Clupeisa.
1. Siluridx.
2. Cyprinidx.
3. Esocida.
4. Clupeidx.
5. Salmonidx.

Obs.-I do not beliere the above places of the families of Balistina to be correct : besides I only know four. I shall say little therefore respecting them, except that I suspect some undiscovered family of BALISTINA leads off to the genus Monocentris, among the Scorpanide. I shall begin therefore with the true PERCINA and the family Scorpanida. The following are the probable genera of Scorpanida, which family agrees with the group called Bucce Loricatc by Cuvier; but it is rather a stirps than a family, and the following genera ought to be deemed of the ranls of families :-

aterrakt Grour.

Hend either tuberculous or spinous.
1. Movocentris, Linn.
2. Trigla, Linn.
3. SCORPENA, Lim.

Free spines in lieu of first dorsal.

Tro distinct dorsal fins.

Tro dorsals more or less confluent.

NorJal gitour.

Head neither tuberculous nor spinous.
4. Oncosossa, Cuv.
5. Gastenosteus, Linn.

Ventrals complete. Free cones in lieu of first dorsal.

Ventrals reduecd to a spine or spines. Free spines in licu of first dorsal.

For subgencra, I must always refer to Cuvier and Valencienncs. 
From Scorpana we proceed by means of the subgenera Sebastes among the Percide, which is a family that I distinguish by having seven branchiostegal rays, no mailed checks, no scales on the fins, and always teeth on the palate.

Probable genera of Percidce.

ABERRANT GROUP.

Two dorsals distinct.
1. Perca, Lim.
Dorsal fins near. Teeth all small,
2. Orogox, Lacep.
3. Exorlosus, $C u$. preoperculum not dentated.
Dorsals separate, some of the teeth long.
Dorsal fins near. Preoperculum den- tated.

TXPICAL Group.

Two dorsals confluent into one.
4. Serranus, Cuv.
5. Ocevins, Cuv. Teeth hooked. Preoperculum den-
tated.

Teeth small, not hooked. I'rcoperculum not dentated.

From Enoplosus we proceed to Ephippus among the Chatodontila, or Squamipexises of Cuvier, of which the following are probably the genera :-

ADERRANT GROUP.

No teeth on the palatines.

1. Epimpus, Cuv.

2. Psertus, Coinm.

3. Chrtodox, Linn.

NORMAL GROUP.

Teeth on the palatines.

4. Toxotes, Cuv.

5. Pesipieris, Cuv.

Dorsal emarginate, so as to shor it to be composed by the confluence of trro. Ventrals distinct.

Dorsal not emarginate. Ventrals evanescent.

Dorsal not emarginate. Ventrals conspicuous.

Dorsal long, opposite to the anal, and reaching close to the caudal.

Dorsal short, opposite to the ventral, aud far separated from the caudal.

From Chatodon wc proceed to Anthiprion among the Sparida, which differ from the Chatodontida by having no scales on the fins, and from the Percide by having no teeth on the palatines. 'The following may be the natural arrangement of Sparide into genera:-

ABERRANT GROLT.

SCLENOIDES, Cuv. Operculum witl spines. Preoperculum dentated.

1. Ampinpriox, $B l$.

2. Pristiposia, Cuv.

3. Scr.x.s, Linn.
One dorsal. Branchial rays less than seven.

One dorsal. Seven branchial rays.

Tro dorsals distinct. Seren branchial rays.

TYPICAL GROUP.

No spines on the operculurn, and the preopcrculum not dentated.

4. Mass, Cuv. Mrnides, Cuv. Upper jaw extensile.

5. Srakus, Lim, Sparoides, Cuv. Upper jaw not extensile. 


\section{W. S. MacLeay on the Natural Arrangement of Fishes. 201}

By means of Polynemus we pass from Sciana to the Cirrhitida, which differ from the Percide in having in general either more or less than seren branchial rays, and from the Sparide in having teeth generally on the palatines. The Cirrhilida, however, differ from each other very much in form, as may be seen by the following grenera, which are clearly of the rank of families:-

'Two dorsals.

1. Polynesus, Linn.

2. Mullus, $\operatorname{Linn}$.

3. Trachusus, Linn.

One dorsal, ventral fins subpectoral.

4. Berrx, Cut.

5. Cirruites, Conem.
Two dorsals distinct. Ventrals sub. abdominal.

Two dorsals distinct. Ventrals subpectoral. Branclial rays less than seven.

Two dorsals united. Ventrals subjugular. Branchial rays more than seven.

Branchial rays more than seven.

Branchial rays less than seven.

By means of Trachinus we return among the Scorpanida, from which we set out, so that the circle of PERCINA is completed. WV now therefore proceed to the next tribe, FISIULARINA, which we enter by reason of the affinity reigning between the Chectodontide and Scombridee, as displayed in such genera as, for instance, Brama and Coryphana.

Probable genera of the Scombrida, or family Scomberoides of Cuvier.

Body regular and pisciform.

1. Corypuena, Linn.

2. Xipuras, Linn.

3. Scourber, Lim. Leading off by Thyrsites to Lepidopus.

Body laterally compressed and vertically elevated.

4. Stronateus, Linn. Ventrals inconspicuous.

5. Zcus, Limn.

Ventrals conspicuous.

By Lcpidopus we enter among the Fistularidce, or long eel-shaped Acanthopterygians, which may be arranged as follows:-

TANOIDES, Cut. One long dorsal. Cranium not produced into a tube. Body tolerably compressed.

1. Lepidopus, Gouan.

2. CePOLA, Limn.

3. Grinetrus, $B l$.
Muzzle clongated; mouth considerably cleft, and a caudal fin present. Mouth considerably cleft; no caudalfin. Muzzle elongated, mouth small, caudal fin present.

FISTULARIDES, Cuv. Cranium produced into a tube.

4. Cextniscus, Linu. Body oval, compressed; scales conspictuous; dorsals trio.

5. Fistularia, Lim.

Body elongated, cylindrical; scales small; only one dorsal.

By Aulostomus we return to Lepidopus, and by means of Gymnetrus and one of its subgenera, Murcuoides, re pass to the Gobioida, a family easily known by the extreme length and tenacity of their dorsal Ann. \&; Mag. N.IIist. Vol.ix. 
spines. The following are possibly the genera which generally have a tubercular appendage to the anus :-

Ventrals not thoracic.

1. Be exwius, Linn.

2. Axarruicas, Linn.

3. Calcioxysus, Limn.
Ventral subjugular, consisting of only two rays. One dorsal.

Ventrals none. One dorsal.

Ventrals subjugular. Two dorsals.

Ventrals thoracic, or placed further back than the pectorals.

4. Mugtu, Linn. Mugiloides, Cav. Ventrals separate. Crea numerous. Two darsals.

5. Gosius, Linn.

Ventrals united at buse. Caeca none. 'Tro dorsals, sometimes confluent into one.

By means of Callionymus, Eleotris and Chirus, we pass to the Lophiida, or Amphibious Acanthopterygians, of which the known genera may probably be as follows; but the truth is, that I have never had an opportunity of accurately examining any of Cuvier's 'Labyrinthiform Pharyngeals.' 'The following genera are cliefly to be ranked as families:-

LABIRINTHIFORII PIIARYNGEALS, Cuv. Carpal bones vo elongated.

1. ***

2. Avabas, Cuv.

3. Opincephates, $B l$.

Spines in the fins?

No spines in the fins?

PEDICLED PECTORALS, Cur. Carpal bones clongated.

4. Bitrachus, $B l$.

5. Lorntu's, linn.

One dorsal.

Two dorsals.

By means of Ophicephalus we pass to the Labrida, or fleshy-lipped Fistularina that lave no spines on their operculum or preoperculum. 'Their genera arc probably' as follows :-

Teeth coucealed by the double lips, which are large and fleshy.
1. Labrus, Limn.
2. Goupiosus, Lac.
3. Xynictiys, Cuv.

Muzzle not protractile. Body not Ialcrally compressed. Oue dorsal. Mouth protractile. One dorsal.

Mouth not protractile. Body laterally compressed. Tro dorsals.

Teeth uncorcred by the lips, which are single.

4. Acsintunus, $B l$. Theutyes, $C u v$. Spines arming some part of the body.

5. Scarus, Limn.

No spinous armature on the body.

By means of Xyrichthys we return among the Scombrida, and so complete the circle of Fistulurina, which is therefore a natural tribe.

Let us now go back to the family Gobioida, and by means of Go. bius we can casily make the transition from the tribe Fistularina to the Malacopteryogian family Cycloptcride, which forms part of the tribe PLEURONECTINA, i. e. Malacopterygian fishes, which have never their rentral fins abdominal. 


\section{W. S. MacLeay on the Natural Arrangement of Fishes. 203}

The families of Pleuronectina are probably as follow; but they are rather stirpes than families :-

ADERRANT GROUP.

1. CYCLOPTERINA. Disconoli, Cut. Ventrals united under throat.

2. ECHENEIIT:.

3. ANGUILLIDE. Arodes, Linn. Ventrals none.

Norsta grour.

4. GADIDA. Gadides, Cut. Symmetrical body, with jugular ventrals far apart from anal fin.

5. PLeuronectide. Platessa, Cutv. Body not symmetrical, laving the ventrals gencrally a continuation of the anal.

Many genera of these families of Pleuroneclina are wanting, so that I can only guess the above to be the natural scries. Brotula and Macrourus certainly show the affinity of Anguillide to Gadida. 'The aftinity of Siluride to Anguillide is vell known, so that we next pass thus to the tribe CLUPEINA, which are Malacopteryginn fishes with abdominal rentrals, $i$. $c$. the same as the group called $A$ BDoninales by Cuvier. We are now more truly on the ground of your 'Monograph on Indian Cyprinicke' and I have little doubt of the following bcing really and truly the families or stirpes of the tribe CLUPEINA, viz.:-

ATIILACENTERA. Intestinal canal not furnished with cxca.

1. SILURIDAE. Silundors, Cuv. No true scales on body; representing I'L $\lambda$ GIOSTOMII.

2. CYPRINIDE. Cyrninoides, $C_{u v}$. Body scaly, mouth slightly cleft; representing CYCLOSTOMI.

3. ESOCID E. Esoces, Car. Body scaly, mouth widely cleft; representing LOPHOBRANCJII.

THYLACENTERA. Intestiual canal furnished with cxca.

4. Cluplid F. Crures, Cuv. No second dorsal; representing OSTINOPTERYGII.

5. SALAIONIDE. Salsionides, Cuc. Second dorsal adipose; representing S'TURIONES.

I am often afraid of trusting myself to Mr. Swainson's method of drawing analogries between things in themselves wide apart. A person may reasonably doubt the legitimacy of any comparison between a fish and an insect, or eren between a fish and a bird; because he may attribute all such resemblances to the imagination, the objects being in themselves so very dissimilar in every leading point of view. But no one can doubt that a fish may legitimately be compared with a fish, and every one will I think sce that there is no effort of the imagination at work when a Silurus is compared with a Chiloscyllium, a Cobiles with Cyclostomous fishes, or some of the mailed Esocidce with the Lophotranchii. The Clupeide represent the Ostinopterygii typically in form, so that I have no doubt you will discover the analogy, as yet unknown to me, which exists between the Salmonidce and Sturiones. I was ignorant of the true arrangement of Cyprinidec until I read your valuable $\lambda$ Ionograph. I have now no 


\section{W. S. MacLeay on the Natural Arrangement of Fishes.}

doubt of its being nearly as follows into genera, or rather into families:-

VERAE, M'Clel. Body regular.

1. PAONOMIN A, M.Clel., or genus Crrninus, $L$. Intestinal canal long; representing STURIONES.

2. SARCOBORIN $\mathrm{E}$, Mr'Clel., or genus Levcrscis, $K l$. Intestinal canal short; representing OSTINOPTERYGII.

APALOPTERINE, M'Clel. Body invested with a slimy nucus.

3. PCECILIANA, MIClel., or genus PocciLiA, Sch. Snout prolonged, no cirri. Branchial rays more than three; representing LOPHOBRANCHII.

4. COBITINE. Mouth provided with cirri. Branchial rags three; CYCLOSTOMI.

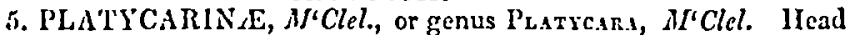
flattened, round and short. No cirri, branchial rays less than three; representing PIAGIOSTOMI.

Thus we see why the Platycara has' the form of a shark; why I.onches, such as Schistura, M'Clel., have an analogy to the Lampreys and Myxines; why Psilorhynchus has so long a snout; and why Gonorhynchus lias the muzzle of a sturgeon. T'The nearer two groups are in general structure, the more striking their parallel analogies will be; and therefore $I$ think, that by comparing fish with fish, we may obtain more striking andugies than by comparing them, as Swainson does, with Mammalia, birds, or insects; at all events, we shall have less reason to distrust the effects of a fertile imagination. Still I am far from denying, that such analogics as he delights in exist in nature. I only say, that they are dangerous things to deal with, and that in his hands they often become far-fetched and even ludicrous. The cause of the greater part of the resemblances which he discovers between objects the most apart from each other in general structure, scems to be a general law of nature, which has ruled that in every group of animals there shonld be a minor group more essentially carnivorous, another minor group more essentially herbivorous, another more aquatic or natatorial, and so on. 'These minor groups may also be characterized by one being more essentially terrestrial, another more essentially aërial, another more aquatic, another more amphibious, and so on. 'Ihese general principles are the occasion of resemblances between animals the most distinct in their structure, and therefore I understand perfectly what Swainson means when he speaks of a Rasorial type of fish ; yet surely it is an incorrect expression, for so far from fishes laving been crcated on the models of Rasores or Grallatores, for all that we know, birds may have been created on Plagiostomous or Cyclostomous types. The general model was undoubtedly one ; but why Swainson should assume this one model to have been taken from birds I cannot divine, except that in ornithology he is most at home. However, to return to the subject of Cyprinidce, your arrangement of them shows another set of analogies, which I also think very conspicuous; for instance,

The Pronomina are the types of the family Cyprinida.

The Surcoborina represent .......... the Esocidx.

'The Pociliana represent . . . . . . . . . . the Clupeidx.

The Cobitina represent ........... the Salmonidx.

The Platycarina represent ......... the Siluridac. 


\section{W. S. MacLeay on the Natural Arrangement of Fishes. 205}

You will perhaps say, that the Cobitince ought to represent the Siluride; but the relation between the Cobitina and Siluride is onc of direct affinity, in which I perfectly agree with Swainson; and I have accordingly made the Cyprinides and Silurida contiguous groups in the table of CLUPEINA, given on a preceding page.

When I can secure a safe private hand, I shall beg your acceptance of a copy of the third part of the "Illustrations of the Geology of South Africa.' In the mean time I must refer you to a copy which I gave our friend Dr. Cantor. In page 9 of that work you will see a Table which is in perfect accordance with your views of the value of the word genus; but not perhaps with your view of the word $f a-$ mily; nor is what I have written above consistent with the view I have taken in that table of the value of the words genus and family. The truth is, what in the foregoing part of this letter arc called Genera, are Families, and ought to end in $i d \omega$, as the peculiar designation of that rank of group ; but as these groups agree wonderfully with the extent of the old genera of Linnous, I left them that name for your more clear comprehension of my meaning. To be consistent, however, with myself in the abore-mentioned table (page 9 of the 'Illustrations'), the following ought to be the gradation of groups:

Regnum.-Animalia. Subregnum.-Vertebrata.

Classis.-Pisces.

Ordo.-Ostinopterygii.

Tribus.-Clupeina.

Stirpes.-Cyprininx, above called 'Cyprinidx.'

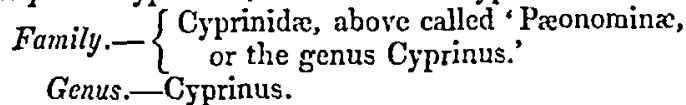
Subgenus.-Tinca.

Section:-and so on to the spccies.

Your table therefore, given p. 261 of your Monograph, is more in harmony (exccpt indeed the names, which are things of artifice, and have nothing to do with nature) with my table given in the "Illustrations' than is the foregoing letter; and I wish you to understand, that were I to publish on Fish, I would make it clearly understood, that I view Linnaus's genera to be groups of the rank of families, so that the groups above called Perca, Scomber, \&c., ought to be called Percide, Scombride, \&c.

I have now written enough to show you how I imagine Fishes may be distributed into something like a natural arrangement. My views must of course be subject to a multitude of corrections; but I think they are more connected, that is, they show more unity, than any ichthyological synopsis which I have jet seen. I have worked out the Plagiostomi with particular care, as my friendship with Dr. Smith made me pay great attention to his unrivalled collection of Sharks and Skates. If you would wish to see the conclusions at which I hare arrived with respect to the Plagiostomi, I shall be happy to send you a sketch in some future letter. In the mean time, you may make what use you please of what I have written in this lettcr, provided it 
be clearly understood, that I am asking naturalists whether such be not the facts of the case, instead of dogmatically insisting upon it that they are. I have no idea of publishing on Fishes, at least for the present.

By the way, I observe that my old friend Colonel Sykes has been describing a number of Indian $C_{y}$ prinide in the 'I'rocecdings of the Zoological Sucicty.' Of course there must be " double cmplois," which I hope you will rectify. I am sorry that I lave not been able as yet to get any Cyprinide from our Nerr Holland rivers; but I altribute it to my own residence so far from any river, not to the absence of them. I am promised by friends, who have belter opportunities, the result of their rescarclies; but $I$ reccive nothing, as they know not how to catch the minute fish of the river. However, I intend to try the Nepean river myself when I go down there, which I soon propose to do. In the mean time, my residence on the sca-side cuables me to increase my collection of mnrine genera, and if there be any you wish for, I shall be most happy to send them. A thousand thanks for your kind method of beating up for insects to be sent me from Indin. I shall be happy to pay any fair price for the collector's time and trouble. Tell I)r. Cantor, that I depend ou him to increase my collection of Aunulose animals, and that I hope he will soon write me. Tell him also, that I have got a marine serpent of the genus Pelamys, caught in the month of Port Jackson harbour, the only one our fishermen have crer seen. If lic wishes for it, it is at his scrvice; for he knows infinitely more of Serpents than I do, and any grand desire is, to increase my collection of $\Lambda$ nnulose animals.

But I could go on writing to you on these subjects ud infinitum, and therefore I trust you will cxcuse any tediousness on the score that my thoughts have been directed into this channel by the perusal of your Monograph. Pray remember me to Dr. Cantor, Dr. Griffith, Mr. Grant, and all who concern themselves with the norks of nature, believing me always,

My dear Sir, your obliged and truly faithful,

V. S. MACLEAY.

October 12, 1810 .

P.S.-As I have had no opportunity of forwarding the enclosed letter, I sit down to make some observations on it that occur to me on now reading it over some weeks after it has been written.

I know not whether you will clearly understand my meaning in making the Cyclostomi the most typical of fishes. Cuvier says that " the Acanthopterygii form the type most perfected by nature;" and in this I agree with him, namely, that their structure is most perfected ; but the Acanthopterygii are not therefore the most typical of fishes, $i$. e. of a class, the greneral character of which is, to be the most imperfectly constructed of Vertebrata. Cuvier talls much of the Acanthopterygii being the most homogeneous in their mariations; but are not the groups of Sharks and Cyclostomi quite as homogencous? Nay, are not Fistularia and Vomer more distinct from each other in form than a Shark from a Skate, or a Lamprey from a Myxine?

There are some relations that require still to be expressed by my foreroing arrangement, such for instance as that of Platycephalus to Eleotris, as that of Sphyrana to certain Esocide, \&c. \&c. Arc all 
such merely relations of analogy? If so, they are expressed; but I cannot help thinking, that the relation is still stronger than that of mere representation.

All geological forms may I think be referred with case to the foregoing arrangement, even the most anomalous in appearance, such as Aphalaspis; for this fossil form may, in my opinion, be understood by looking at the head of Platyccphalus. Howerer, the most extraordinary forms of fossil fish belong to the Ganoids of Agassiz, or rather to the Sturiones, and those other orders of the class Pisces that present the fewest existing forms. But on this head I shall at once frankly say, that if any fossil forms can be shown not to fall into a place in the preceding arrangement, then my general riew of Ichthyological affinities is wrong; for I am convinced that there is but one system for all animals, whether Antediluvian or not. I shall write you on Echinida in my next, and eend you eome the very first opportunity.

XXV.CContributions to the Ichthyology of Australia. By Jomi Richandsov, M.D., F.R.S., \&c., Inspector of IIospitals, Haslar.

[Continued from p. 131.]

Uranoscopus maculateus (Forster), Bearded Uranoscope. Uranoscopus maculosus, Soland. Pisc. Mustr. MISS. p. 21.

maculatus, G. Forst. ; Fig. Nos. 176, 177, Banks. Libr.

- monopterygius, Bl. Schn., p. 49, ex notis J. R. Forsteri, nomine specifico ejus mutato.

Lirrhosus, Cuv. \& Val. iii. p. 314. An. 1829.

Forsteri, Id. iii. p. 318 .

Wouripoua, Less., Voy. \&c. par M. Duperrey, 1830, pl. 18.

On Cook's first voyage a Uranoscope with a single dorsal was procured at 'lolaga, in latitude $38 \frac{1}{2}^{\circ}$, New Zcaland, the colours of which were briefly described by Solander in his 'Pisces Australia;' but as the details of structure were not given, and no figure was taken, it remained for future observers to furnish a proper character of the species. On the second voyage of our immortal navigator this Uranoscope was again obtained on the coast of New Zealand, at Queen Charlotte's Sound, in latitude $41^{\circ}$. The two pencil sketches above quoted were on this occasion made by George Forster, and in 1801 the species was described under the designation of monopterygius by Schneider in his posthumous edition of Bloch, from the manuscripts of J. R. Forster. The term maculatus is inscribed on G. Forstel's sketches, and it is also noted that the native name of the fish is 'Bedee.' Just fifty years after Cook's sccond royage, M. Lesson, one of the naturalists of La Coquille, commanded by Capt. Duperrey, discovered the same species, or one very nearly alike, in the Bay of Islands, where it bore the 